\title{
First Grade Teachers' Expectations of Children's Skills in Transition to Primary School
}

\section{Lara Fridani*}

Centre for Empowerment and Research Australia

*lara.fridani@cfer.org.au

\begin{tabular}{ll}
\hline Article Info \\
\hline Received $\quad: 2019-06-11$ \\
Accepted : 2020-01-12 \\
Published : $2020-01-28$ \\
\hline
\end{tabular}

Key words: first grade teachers' expectations; children's skills; transition to primary school

Abstract
This study investigated first grade primary school teachers'
expectations of children's skills entering primary school in Jakarta,
the capital city of Indonesia. The aim of the study was to provide
some reasons or beliefs that form teachers' expectations regarding
children's competency and learning in their first year of primary
school. The study was conducted using a qualitative approach which
involved 30 first grade primary school teachers across Jakarta's
regions (Centre, East, West, South, and North). The Focus Group
Discussion was used as an instrument that provides a forum for
teachers to describe their expectations. The study employed the
Ritchie and Spencer's qualitative analysis framework analysis
approach (1994) which involved five key stages: familiarization,
identifying a thematic framework, indexing, charting and mapping,
and interpretation. The results showed that expected academic skills,
teachers' competency, and educational policy were the key variables
that informed teachers' expectations. The findings of this study have
demonstrated that it is crucial to support teachers professional
development as their knowledge and expectation may greatly affect
the way teachers treat their students.

\section{Introduction}

During the last two decades, discussion surrounding educational transition has increased due to the brain research which has explained its contribution to children's future successful learning both socially and academically (Dockett \& Perry, 2007; Fabian \& Dunlop, 2007). The topic of children's transition to primary school has actually been an issue of educational research and practice, as well as a question of educational policy for over one century (Brostrom, Vrinioti, Einarsdottir, 2010). Transition program is related to providing a bridge from prior to school to school settings that may occur over the long term (Dockett \& Perry, 2007). The scholars explain that transition involve many experiences in which educators and services contribute to the general well-being of children and their families in the preparation for school. Astbury (2009) restates that in order to make transition effective, children must be supported to feel valued, comfortable and ready to learn.

It is confirmed that first grade is a critical period in children's education in which the foundation for the rest of the primary grade is set. It is also noted that children are entering primary school with a variety of academic skills. Some children have basic academic knowledge such as letters of the alphabet, whereas others have moved to build crucial academic skills in reading, writing, and counting. Therefore first grade teachers must have certain knowledge and ability to adapt their teaching to children from diverse background academic experiences (Gravett \& Peterson, 2017).

Early, Pianta, Taylor, and Cox (2001) suggest that teachers' competency is crucial to face the challenges and obstacles in the process of children's transition to school. Teachers should have knowledge about the importance of all aspects of children's development, especially in the early school years as it links to a better performance or success in learning. Children who lack the social emotional and academic skills are at risk for trajectories of 
increasing academic failure and behavior problems over their school years (Entwisle \& Alexander, 1999). Other scholars, Janus and Offord (2000) recommend the importance of teachers' knowledge to move beyond academic preparation and consider the importance of children's learning which involve social competence, physical health, emotional adjustment, language and cognitive skills, and general knowledge. Fattore, Mason, and Watson (2007) argue that transition programs that take children's overall wellbeing into consideration are found to be more effective than those that focus on academic potentials alone. Fisher (2008) describes some concerns about children's experiences to primary school and identified some challenges to transition that being posed by the move from a play - based approach to a more structured curriculum in their early learning. In addition, Mashford-Scott, Church and Tayler (2012) argue that it will be difficult for any learner, including a child, to make significant gains in education if they feel their wellbeing is threatened. Children who feel overwhelmed and stressed with school tasks may develop behaviour problems. Thus, it is important that teachers have understanding to analyse their program and support children's wellbeing who are entering primary school. Teachers' understanding within the context of school is crucial as it influences their priorities in teaching certain skills for children (Griebel \& Niesel, 2002).

Besides knowledge, teachers' expectation is also an important component that may impact on children's transition. Expectation is a belief that is centered on the future that may or may not be realistic. However, teachers' expectation may greatly affect the way teachers treat their students. Petriwskyj, Thorpe, and Tayler (2005) suggest that teachers' high expectations and discontinuities in teaching style are the factors that lead to difficulties in children's transitions. Other scholar ( Peters, 2010) states that teachers must have positive expectations for all their students and suggest some important aspects of transition such as helping children develop a sense of belonging and well-being at school; acknowledging children's values, languages and cultural knowledge, getting children deeply engaged in learning that is suitably interesting and challenging, helping children establish a positive identity as a learner, and encouraging a positive disposition towards learning.

Many countries in the world have extensive literature regarding the practice of transition from various perspectives (Cassidy, 2005; Dockett \& Perry, 2005; Dunlop \& Fabian, 2003; Peters, 2000). Many of the studies view transition to school in an ecological frame, which is more complex than the child centred perspective that considers children's skills to be the most important factor. The model entails building relationships between all stakeholders such as children, families, educators and communities (Bronfenbrenner \& Morris, 1998; Sayers, Moore, Brinkman, \& Goldfled, 2012). Further, due to cultural, economic and school policy disparities, different countries have tended to apply diverse concepts, approaches and practices of children's transition to primary school (Rosier \& McDonald, 2011; Vogler, Crivello, \& Woodhead, 2008).

While much has been written about transition in western countries, there have been few published studies on transition to primary school in Asian Countries, especially in Indonesia. Fridani and Lestari (2008) documented a collection of case studies on primary school teachers' practices in few regions around Jakarta, the capital city of Indonesia. It was found that the teachers tend to have high expectations, and pressure their students to study well on academic subjects. Some primary schools those labelled as having a 'better standard' prefer to accept children with good academic skills before being considered eligible to enter primary school. Further research regarding teachers' perspectives and practices on school readiness and transition (Fridani, 2014) described kindergarten and primary school teachers' attitudes and concerns regarding children who do not meet the 'expected standards' of teachers in the class. However, little is currently known about teachers' expectations of children's skills in transition to primary school and the belief they have about children's learning. Therefore taking into consideration this issue, the researcher would like to fill this gap. 


\section{Methodology}

The purpose of this study requires gathering relevant data from primary school teachers on their expectation of children's skill entering primary school. Considering the nature of the questions, this research is met within an interpretivist paradigm alone that uses qualitative method (Silverman, 2000). The research questions are (1) what are the expectation of first grade teachers of children's skills in transition to primary school? (2) Why do teachers belief that those skills are important?

In this study, the researcher used a qualitative analysis and interpretation. The Focus Group Discussion (FGD) is used as an instrument that provides a forum for first grade teachers to describe their expectation and discuss their reason for having that expectancy. The FGD is important in generating data through group interactions on generic questions of the research (Creswell \& Plano-Clark, 2007). The samples of the FGD included: What skills do you expect from children entering primary school ? What is your consideration for having the expectation?

Participants; The target population for this research was first grade primary school teachers in five regions of Jakarta. Overall, a simple random sampling was used to select school sites and teacher participants. To obtain a comparable number of participants in each region of Jakarta, the researcher randomly selected a subset of schools from which she invited all of the teacher participants.

Due to the considerable size of Indonesian Islands and the potential primary school teacher population across Indonesia, the study demographic has been reduced to Jakarta. There were 30 participants across the research sites comprising of 5 groups across Jakarta's regions (Centre, East, West, South and North) from primary school settings. The majority of first grade teachers worked in public primary schools. All the primary school teachers were between 25-34 years with various teaching experiences. The average number of students per class in the primary schools was about 35 to one teacher.

The Focus Group Discussions. The main argument for using FGD is related to its collective nature. The FGD provided a space to articulate teachers' thoughts easily and useful in exploring as well as analysing participants' reasons to their thinking and actions in a nonthreatening way (Kitzinger, 2005). The FGD involved 30 first grade teachers comprising of 5 groups across Jakarta's regions. Each group consisted of 6 - 8 first grade teachers from various schools. During the FGD the researcher used a digital recording device to record the proceedings for later transcription and analysis. In addition, she wrote notes about the teachers' answers as a complement to the voice recording. Each group lasted for about one hour.

The qualitative data analysis. The qualitative data were obtained through the FGD and the analysis involved the use of Ritchie and Spencer's framework analysis (1994) with five key stages: familiarization, identifying a thematic framework, indexing, charting and mapping interpretation. This method enables themes to be developed both inductively from the FGD and supported with deductive application of related research literature. The specific steps taken to do this are follows: (1) Familiarization with the data. The researcher thoroughly read and re-read each transcript, and listened back to the audio-recorded FGD to become familiar with the whole data set. Familiarization through reading and making notes also enabled the researcher to negotiate through several pages of transcript later in the analysis; (2) Coding to identifying a thematic framework. The researcher develops a coding scheme and code the data in order to identify a thematic framework. The researcher started by underlining interesting segments of the transcripts and used the left hand margin to describe the content of each passage with a coded label. The right hand margin was used to record more detailed notes and ideas; (3) Indexing. After the researcher had open-coded all the transcripts she went through all the coded data to ascertain the meaningfulness, what it expressed about participants' expectation on transition and how it might be useful for answering the research questions; (4) Charting. Once all the data had been coded using the analytical framework, the researcher summarized the data 
in a matrix for each theme.; (5).Mapping and interpretation. Themes were generated from the data set by reviewing the matrix and making connections within and between thes groups and categories. The researcher revisited the objectives of the study and research questions as reference points in addition to novel conceptual ideas generated inductively from the data. To gain further insights into the data at this stage of the analysis, the research drew upon relevant theoretical ideas and literature which for the foundation of the study to extend the interpretation of the findings.

\section{Results}

There are three key themes that emerged from the FGD, namely (1) Expected Academic Skills, (2) Teachers' Competency, and (3) Educational Policy. Each theme was further explained and typical comments were noted to corroborate the findings. Representative quotes from the FGD have been reproduced to reflect each of the three themes.

Expected academic skills. The findings indicated that the majority of primary school teachers (ps teachers) expected children entering their class with basic academic skills such as reading, writing and counting. There were some of them demonstrated a broader understanding of children's development aspects such as physical health and social emotional dimention. However, some of them ended up with arguments suggesting their concerns for children who do not have those academic skills. Therefore, some of the groups argued about the importance to implement basic academic test for children before entering primary school. However, this group convinced that the test they gave was not difficult for children, as a primary school teacher group stated:

We had a test for children entering ps about reading, writing and some basic math. We did not give a difficult test. We believe that children should have these skills to be able to read, write and count (Ps1).

Related to ps teacher groups' expectations, they mention about the importance of children's basic knowledge in reading, writing and counting and 'the benefit' of previous selection tests, as some ps teacher group explained:

Actually, the last few years, we cannot conduct an academic test related to children's selection to enter public primary school. However, we do expect our children to have reading, writing and counting skills (Ps2).

We hope that children entering our school already have the basic academic skills. It would be easier for them to learn subjects in primary school. So even though we can not conduct a local test for them, at least we can select children from kindergarten that already teach them those skills. Just like previous years (Ps4).

The data further showed that although the majority of the primary school teachers understand that academic skills are not the requirement for children to study in primary school, the teachers expressed their concern for children having limited skills in reading, writing and counting. These concerns were raised by stating that:

We realize that academic skills are not the requirement. But in practice, we are sure theat learning in primary school is different from kindergarten. The curriculum target is different. Children at grade one already have a long reading list to read...it needs their reasoning as well...it need those basic skills (Ps3).

It can be argued that many of the teacher participants were being driven by the prevailing conditions in primary schools. It can be implied that failure to follow the line of what is happening in the primary schools would place their children at risk as indicated in the following statements:

We hope that children who entering ps are able to read, write and do basic arithmetic. Based on our experience, those children who can neither read, write, nor do basic arithmetic in our school would find difficulty in understanding their lessons. It would become a big challenge for them in the future (Ps4). 
These comments indicated that in general, the ps teachers were not happy with the diminishing nature of selection tests for children who are seeking to enter primary school. Their expectation on children to have basic knowledge of academic skills are based on their consideration and experience that those skills is needed in order to cope with curriculum or programs in primary school settings.

Teacher's Competency. The results indicated that the first year teachers faced some challenges when teaching young children. Some of the challenges were related to their competency to cope with large numbers of children in their classes. They shared their challenges pertaining to their competency in handling many children in the class with their related problems including the following:

We have some problems with many first year students in our class... it is around 40 students and there is only one teacher to teach them. Even though some of them can read, write, and count well, but still they do not want to listen to our instructions. Some of them are quite active and sometimes disturb other children ...it is not easy to handle this class situation (PsI).

We follow the policy, to accept all children regardless of their skills.... we just limit the number of children in our class to a maximum of 40 children.... We have to try very hard to make them feel comfortable in the class then they may concentrate on our explanations. We found it quite challenging because we do not have the appropriate skills to reduce their anxiety at school and not to be scared with new teachers. Moreover... we have jobs to teach them to read, write and count. This will be another problem (Ps5).

In addition, some ps teacher groups raised an issue on the target of learning for children which has to do with many subjects to be taught in the curriculum.

We have lots of things to do primary school. We have to teach them more subjects to learn such as math, language, science, moral education, etc. We believe that it is not eady for them too, but we have to accomplish the learning target in the curriculum (Ps3).

We have to make sure that our children are on the track for primary learning. This is crucial so they can move on to learn more subjects based on the curriculum...we found some children are behind their peers and this is tough for us to solve the problems at once. Some of us decide to provide extra classes to teach the children, especially those who are not good at reading, writing and counting. So this is an additional work (Ps4).

The teacher groups' explanations highlighted their big effort to support the children to reach the learning target prescribed in the curriculum. Even though some teacher groups recognized the difficulty that children have to cope with, they seemed not to have any options. Their approaches did not take into account children's developmental potentials, differences and individual characteristics.

One unexpected practice confirmed by some teachers was the implementation of a routine test for grade one children which is organized by some teachers' groups. Some teachers reported:

We have to manage our teaching program and our time very well, if not, our children cannot reach the target. We delivered some routine tests for them as an exercise so they can accelerate their learning (Ps3).

The teachers' statements above implied their limited understanding of the impact of formal tests, which involved paper and pencil responses from young children. The teachers appeared to consider the tests as integrally tied to the curriculum. It seemed that the teachers are concerned with the product of learning instead of the process of learning.

Educational Policy. Regarding transition programs in primary school, all the ps teacher groups shared their practices with reference to government's recommendation or policy. These teacher groups seemed more convinced in explaining the requirements for children to be 
accepted into primary school. The following quotes are examples of how majority of the groups showed their awareness and compliance to the policy:

It is stated that children who are at least six years old can be accepted in primary school. We follow the policy and the requirements recommended by government. We do hope that those who would be accepted are children who are ready learning at school (Psl).

We are a public primary school, so we follow the government policy to select children only based on their age. The older children will have more opportunity than the younger ones. (Ps3).

Primary school teacher groups also shared their experiences about the effect of age criteria policy, and that it increased their burden in teaching children in primary school. Some primary school teacher groups commented by saying:

Telling you the truth, this policy sometimes put us in a such difficult situation... One the one side, we have to select children entering primary school only based on their age. On the other side, having students with older age, does not mean they have a better skills of reading, writing and counting. This is another problem for us (Ps2).

With the policy, we have to accept all the children registered in our school whether they can read or not. Based on our past experiences, some of the children coming to our school are not ready to learn... It becomes an extra job (Ps5).

The above comments suggest that some teachers were not comfortable about the policy specifications. In this regard, they thought that this policy created additional responsibility for them.

On the other hand, one primary school teacher group viewed the value of this age criteria policy from another perspective. They shared their thought as follows:

We belong to public primary schools...so we refer to the government's policy including the age criteria policy. In our view this is good and fair, we just consider children's age...we do not see whether these children are smarter than others... so it will limit the favoritism and nepotism (Ps1).

\section{Discussion}

The first and second research questions of this study require gathering and analyzing opinions of ps teachers, to describe their expectations towards children's skills entering primary school. It is widely accepted that teacher's expectation and belief may affect what they would accomplish in their class. Understanding first grade teachers' expectancy is important as they are part of the primary influences on children's development and learning (Bingham \& Whitebread, 2012). The findings to the first and second research question can be discussed under two main ideas namely: (1) Describing teachers' expectations of children's skills entering primary school and (2) Explaining teachers' belief regarding the importance of children's academic skills.

\section{Describing teacher's expectation of chidlren's skills entering primary school}

Regarding the requirement of children's transition to primary school, the teacher participants follow the government's policy regarding age requirement for children entering primary school. The teacher participants are teaching in public primary schools so they have to submit to the policy. In other words, the teacher groups' compliance with the government policy is the direct result of them being under the government's supervision in which they must adhere strictly to the policy requirements or face sanctions (Sardjunani \& Suryadi, 2005). The existing nature of the education policy in Indonesia context seems to influence teachers' decision in implementing their programs. It also shows that the policy has a significant impact on the teachers' way in facilitating programs for the children's transition.

However, teachers' compliance does not represent the majority of ps teachers' expectation towards their new students. Further findings from FGD indicated that majority of teacher groups expect children to have a basic academic skills before entering primary school. 
To these teachers, age as the only criteria of school entry are not as they are expected. They argue that it may cause learning problem when those children do not have certain basic skills. They believe that without having the academic skills, would situate children to failure. Teachers' expectation toward children to have basic academic skills is quite worrying as their thought of children's development in cognitive terms alone. The arguments in favour of children being taught academic skills appeared to construct children solely in terms of cognitive development (Halle, Zaff, Calkins, \& Margie, 2000). It can be argued that this perception situates children in an empiricist perspective which identifies children by focusing on the predetermined set of cognitive skills and knowledge considered prerequisites for later success in school (Marquez, 2006). A belief in the empiricist view suggests that development is stimulated by learning and is not a prerequisite for it (Berk \& Winsler, 1995). The empiricist view addresses that children should be trained in certain related skills followed by universal testing on specific curriculum tasks or through universal standardized instruments. Instead of focusing on cognitive skills alone around reading, mathematics and writing, educators must play a role in providing children with appropriate social opportunities and scaffolding early experiences needed to develop significant social and learning skills needed for school entry (Carlton \& Winsler, 1999).

Some researchers highlight that older children at school entry, do better academically in the short and longer terms (Lin, Freeman, \& Chu, 2009) However other scholars found that age of entry does not really matter for children's academic progress and well-being (Berliner, Robert, \& Calfee, 2013). Therefore, holding children back because of their age will not guarantee they will learn better or be in less danger of academic risks. In fact, there will always be a younger group of children and a range of abilities represented in the classroom (Cannon \& Libscomp, 2008). Thus, decisions over which children are considered younger or older by teachers can be quite subjective.

Another key finding regarding teachers' expectation is about the implementation of academic test practice for children before entering primary school. The teacher participants actually understand the recent government policy for not taking any academic test as the selection process for children entering primary school. However, some teachers have expectation and argue the benefit of the selection test practice for children. The participants clarified their logic related to the practice of selection tests in determining children's readiness to study in primary school. It is unexpected that that teachers view children as the center of the problem by prioritizing testing before they enter school. It seems that they do not understand the negative effect of this practice for young children. The practice is harmful and may increase pressure on children. It also lead to labelling children who may fail on these tests as deficient (Amsterlaw, Lagattuta, Meltzoff, 2009). Therefore it is crucial for teachers to move beyond academic conceptualization and consider the importance of less structured aspects of early childhood learning such as social competence, physical health, emotional adjustment, language and cognitive skills, and general knowledge (Janus \& Offord, 2000; National Education Goals Panel, 1992). The teachers should also be informed that instead of testing children, it is teachers' role and responsibility to develop the whole child through the provision of ongoing support and enable environments for rich experiences and optimize children's development (Daily, Burkhouser \& Halle, 2010; Dockett, Perry, \& Kearney, 2010). An academically oriented skill priority for children entering primary school is contrast to recent findings that advocate for a broader and more holistic prioritization of school readiness (Rosier \& McDonald, 2011).

Many research findings have made it clear that children's education and later life success depends not only on children's cognitive skills, but also on their physical and mental health, emotional well-being, and ability to relate to others (Hair, Halle, Terry-Humen, Lavelle, Calkins, 2006). Therefore, it is crucial to provide the quality of the early childhood environment experienced by the child, as it helps to lay the foundation for future development 
critical for important outcomes of children's learning and thinking (Fox, Levitt \& Nelson, 2010).

\section{Explaining teachers' belief regarding the importance of children's academic skills}

The result of the FGD showed teachers are lacked adequate of contemporary child development knowledge as their practices appear inappropriate with current research. For example, they believe that children with no basic academic skills will experience difficulty in learning subjects in primary school. Many researchers (Fantuzzo, Bulotsky-Shearer, Mc Dermott, Wayne, Frye, \& Perlman, 2007) have reported that one of the factors that contribute to children's achievement at school is associated with positive learning approaches. According to Hyson (2008), learning approaches are important because they can enhance or detract a child's ability to learn. Instead of describing what children learn with regard to specific content areas, approaches to learning must focus on how children learn across varied curricular tasks. By attending to approaches that are conducive to learning, teachers can make a critical contribution to early school success (Copple \& Bredekamp, 2006). In this regard, teachers' competency are needed to bring into play a variety of teaching strategies that can encompass the great diversity of children in schools. Excellent instructions build on what children already know and can do and provide knowledge, skills and dispositions for lifelong learning (Neuman, Copple, \& Bredekamp, 1998).

Other teacher's reason was related to their increased amount of work because of children's poor performance in academic skills. Teachers were highly concerned that the abolishing of selection tests would open the door to many children who are not yet ready to cope with primary school task to enter school, which would lead to increased workload. They made this claim in the light of the extra support they have to give to those children they deem not ready for primary school. In general, there was a feeling of discomfort among the teachers regarding 'no tests' and instead to rely on children's age as the main determinant of their readiness for primary school. Given these situation, teachers worry that their children may not have the necessary skills to learn in primary school. In general, it appears that the current public policy demands that Indonesian schools meet certain standards. For this reason, children entering primary school are often expected to have at least basic academic skills. The findings suggest that there is a gap between current policy and practice in which many teachers are introducing formal structures to support children to learn smoothly in primary school. Further, teachers explained that they are already required to do numerous tasks such as classroom teaching, lesson planning and teacher meetings which sometimes cannot be handled on their working day. They also have to devote their time to teaching literacy and numeracy considering 'the requirement' at schools and high expectation from children's parents.

Regarding this issue, Chan (2010) suggest that teachers' competency is crucial in facing the challenges and obstacles in the process of children's early learning including the knowledge to prepare transition activities, the skills in promoting family engagement, and reaching out to families and promoting children's growth, development and learning. Rivkin, Hanushek and Kain (2005) argue that teachers' competences have powerful effects on children's achievement in which up to three quarters of school effects on children's outcomes can be explained by teacher effects. Other scholars emphasize the importance of teacher's competency in knowledge, cognitive and practical skills, as well as dispositions such as motivation, beliefs, value orientations and emotions (Rychen \& Salganik, 2003); competency to act professionally and appropriately in a situation (Koster \& Dengerink, 2008) and to demonstrate a certain level of achievement (González \& Wagenaar, 2005).

Another problem identified by teacher participants is related to large class sizes. However, it is argued that over class size hass been associated with student's academic performance (Blatchford \& Russell, 2019). Many teacher participants believed that class size affected how they supported children's transition to school. In the Indonesian context, high teacher - child ratio is very common and it is not easy to avoid. According to Harmer (2000), 
teaching large classes brings difficulties to both teachers and children in the process of teaching and learning. On the part of children, it can lead to disruptive behaviours and lack of individual attention (Early, Pianta, Taylor \& Cox, 2001). On the part of teachers, as Locastro (2001) has argued, it can create pedagogical, management-related and affective problems.

The issues on teachers' limited competency is probably due to the Indonesian teachers' educational background. In this study almost half of the teacher participants had diploma qualifications. The rest had qualification from undergraduate Actually, it has been a problem for early childhood teachers including primary school teachers in Indonesia in terms of teachers' qualification. It is also believed that teacher's training for professional development plays a critical role as they view that individual teachers are the single largest factor that adds value to children's learning (Cochran-Smith, 2005) and having the most significant impact on children's outcomes (Hattie, 2003). In addition, it is acknowledged that the availability of policies is important for establishing guidelines, procedures and standards as well as support for teachers in order to facilitate children's quality learning (Kagan \& Rigby, 2003; Rosier \& McDonald, 2011). Without government support, schools would lack the direction and structure upon which they need to provide educational support that meets children's needs. Raver (2002) recommends that policy makers at the local levels must capitalize on public support for developing readiness programs that include a range of possibilities for children's emotional adjustment as well as their academic skills.

\section{Conclusion}

The expectations of first grade teachers on children's skills entering primary schools are based on their common misunderstanding of children's development and learning. The findings of this study suggested that majority of primary school teacher expect children to have basic academic skills before entering primary school. They believe that without having those skills, would situate children to failure. Besides, a big class size in public primary school would affect how they support children's skills. In Addition, children's poor performance in academic skills would increase their amount of work. In this regard, teachers have to be informed about contemporary practices of supporting children's skills at primary school through efficient and relevant training. It is hope that they would possess the requisite knowledge and skills to support children's learning and have an insight to develop continuous approach for children's transition.

\section{Limitation}

This research study has some limitations related to the scope of the study and participants. As teacher participants in this study representing urban communities, the findings of this study can be said to provide some evidence which may not be generalizable, although relevant to communities and schools in rural parts of the country. Further, the diverse issues of primary school teachers were not fully represented in this study without considering the voices of other stakeholders involved in children's learning. Despite these limitations, the study provided relevant information on what is currently going on in children's transition entering primary schools.

\section{References}

Amsterlaw, J., Lagattuta, K. H. \& Meltzoff, A. N. (2009). Young children's reasoning about the effects of emotional and physiological states on academic performance. Child Development, 80( 1), 115-133.

Astbury, B. (2009). Evaluation of transition: A positive start to school pilots. Centre for Program Evaluation. The University of Melbourne. 
Berk, L. E. \& Winsler, A. (1995). Scaffolding children.s learning: Vygotsky and early childhood education. Washington, DC: National Association for the Education of Young Children. (ERIC Document No. ED384443).

Berliner, D. C., Robert, C. \& Calfee, R.C. (2013). Handbook of Educational Psychology. Routledge, Taylor and Francis group.

Bingham, S. \& Whitebread, D. (2012). School Readiness; a critical review of perspectives and evidence. TACTYC occasional paper 2. University of Cambridge.

Blatchford, P. \& Russell, A. (2019). Class size, grouping practices and classroom management. International Journal of Educational Research, 96, 154-163.

Bronfenbrenner, U. \& Morris, P. A. (1998). The ecology of developmental processes. In W. Damon (Series Ed.) \& R. M. Lerner (Vol. Ed.). Handbook of child psychology, 1. Theoretical models of human development (5th ed., 993-1028). New York: Wiley.

Broström, S., Vrinioti, K. \& Einarsdottir, J. (2010). Transitions from preschool to primary school. In Müller, H.: Transition from preschool to school:Emphasizing early literacys comments and reflections by researchers form eight European countries. Cologne: EUAgency, Regional Government for Cologne/Germany. 16-20 www.ease-eu.com.

Cannon, J. S. \& Libscomp, S. (2008). Changing the Kindergarten Cut off Date: Effects on California Students and Schools. Public Policy Institute of California.

Carlton, M. P. \& Winsler, A. (1999). School readiness: The need for a paradigm shift. School Psychology Review, 28, 338-352.

Cassidy, M. (2005). They do it anyway: A study of Primary 1 teachers' perceptions of children's transition into primary education. Early Years: Journal of International Research \& Development, 25(2), 143-153.

Chan, W. L. (2010). The transition from kindergarten to primary school, as experienced by teachers, parents and children in Hong Kong. Early Child Development and Care, 180(7), 973-93.

Cochran-Smith, M. (2005). The unforgiving complexity of teaching: Avoiding simplicity in an age of accountability. Journal of Teacher Education, 54(1), 3-5.

Copple, C. \& Bredekamp, S. (2006). Basics of developmentally appropriate practice: An introduction for teachers of children 3 to 6. Washington, DC: National Association for the Education of Young Children.

Creswell, J.W. (2007). Qualitative inquiry and research design: Choosing among five approaches. Thousand Oaks, CA: Sage.

Daily, S., Burkhauser, M. \& Halle. T. (2010). A Review of School Readiness Practices in the States. Early Learning Guidelines and Assessments. Early Childhood Highlights, 1 (3).

Dockett, S. \& Perry, B. (2005). "You need to know how to play safe": Children's experiences of starting school. Contemporary Issues in Early Childhood, 6(1), 4-18.

Dockett, S. \& Perry, B. (2007). Starting school: Perceptions, experiences and expectations. Sydney: University of New South Wales Press.

Dunlop, A.W., \& Fabian, H. (2003). Editorial. European Early Childhood Education Research Journal. Transitions: Themed Monographs series, 1, 2-4

Early, D. M., Pianta, R. C., Taylor, L. C. \& Cox, M. J. (2001). Transition practices: Findings from a national survey of kindergarten teachers. Early Childhood Education Journal, 28(3), 199-206. 
Entwisle, D. R. \& Alexander, K. L. (1999). Early schooling and social stratification. In Robert C. Pianta and Martha J. Cox (eds.). (pp. 13-38). The Transition to Kindergarten. Baltimore, MD: Brookes Publishing.

Fabian, H., \& Dunlop, A.W. (2007). (eds). Informing Transitions: Research, Policy and Practice. Maidenhead, Berkshire: Open University Press/McGraw-Hill.

Fantuzzo, J., Bulotsky-Shearer, R., McDermott, P. A., McWayne, C., Frye, D. \& Perlman, S. (2007). Investigation of dimensions of social-emotional classroom behavior and school readiness for low-income urban preschool children. School Psychology Review, 36(1), 44-62.

Fattore, T., Mason, J. \& Watson, E. (2007). Children's conceptualisation(s) of their wellbeing'. Social Indicators Research, 80(1), 5.

Fisher, J. (2008). Starting from the Child: teaching and learning in the foundation stage. Maidenhead: McGraw-Hill.

Fox, S., Levitt, P. \& Nelson, C. (2010). How the timing and quality of early experiences influence the development of brain architecture. Child Development, 81(1), 28-40.

Fridani, L. \& Lestari, A. (2008). Inspiring education: studi kasus dan pemecahan masalah di sekolah dasar. Jakarta: Elexmedia komputindo.

Fridani, L. (2014). School Readiness and Transition to Primary School: A Study of Teachers, Parents, and Educational Policy Makers' Perspectives and Practices in the Capital City of Indonesia. Unpublished PhD thesis. Monash University, Australia.

Gravett, S. \& Petersen, N. (2017). 'Foundation teachers are more than simply childminders. Here's why', The Conversation, viewed 10 September 2017, from https://theconversation.com/foundation-teachers-are-more-than-simply-childminders-hereswhy-71943

Griebel, W. \& Niesel, R. (2002). Co-constructing transition into kindergarten and school. In : Fabian, H. and Dunlop, A-W. A. (eds.).Transitions in the Early Years: Debating continuity and progression for children in early education. London, UK: RoutledgeFalmer.

Hair. E., Halle, T., Terry-Humen, E., Lavelle, B. \& Calkins, J. (2006). Children's school readiness in the ECLS-K: predictions to academic, health, and social outcomes in first grade. Early Childhood Research Quarterly, 21(4), 431-54.

Halle, T., Zaff, J., Calkins, J. \& Margie, N. G. (2000). Background for community-level work on school readiness: A review of definitions, assessments, and investment strategies. Washington, D. C. : Child Trends.

Hattie, J. (2003). Teachers make a difference: what is the research evidence?. Australian Council for Educational Research, annual conference.

Heckman, J. J. (2006). 'Skill Formation and the Economics of Investing in Disadvantaged Children. Science, 312, 1900-1902.

Hyson, M., Copple, C. \& Jones, J. (2006). Early childhood development and education. In K. A. Renninger \& I. Sigel (Eds.), Handbook of child psychology: Volume 4. Child psychology in practice (pp. 3-47). New York: Wiley.

Jacobs, G. M. (2001). Providing the scaffold: A model for early childhood/primary teacher preparation. Early Childhood Education Journal, 29, 125-130. DOI: 10.1023/A:1012581113983.

Janus, M. \& Offord, D. R. (2000). Readiness to learn at school. ISUMA, 1(2), 71-75. Retrieved April 7, 2008, from http:// www.offordcenter.com/readiness/pubs/publications.html. 
Janus, M. \& Offord, D.R. (2007). Development and psychometric properties of the Early Development Instrument (EDI): a measure of children's school readiness. Canadian Journal of Behavioural Science. 39(1), 1-22.

Kitzinger, J. (2005). Focus group research: using group dynamics to explore perceptions, experiences and understandings. Holloway I. (ed.). Qualitative Research in Health Care Maidenhead: Open University Press.

Lin, H., Freeman, L. S. \& Chu, K. (2009). The impact of kindergarten enrollment age on academic performance through kindergarten to fifth grade. European Journal of Social Sciences, 10(1), 45-54.

Marquez, H.B. (2006). School Readiness: Kindergartners' Social Development and Developmentally Appropriate Classrooms. Published Doctoral Dissertation, Kansas State University.

Mashford-Scott, A., Church, A. \& Tayler,C. (2012). Seeking children's perspectives on their wellbeing in early childhood settings. International Journal of Early Childhood, (44), 231247.

National Education Goals Panel. (1992). "The national education goals report: Building a nation of learners." Washington, DC: Author.

Neuman, A. C. (1996). Late-onset auditory deprivation: A Review of Past Research and an Assessment of Future Research Needs. Ear and Hearing, 17(1), 3-13.

Neuman, C. J. (2002). Humanistic psychological assessment in a forensic setting. The Humanistic Psychologist, 30(1-2), 150-163.

Neuman, S. B. \& Celano, D. (2001). Access to print in low- and middle-income communities: An ecological study of 4 neighborhoods. Reading Research Quarterly, 36, 8-26.

Neuman, S. B., Copple, C. \& Bredekamp, S. (1998). Learning to read and write: Developmentally appropriate practices for young children. Washington, D.C.

Peters, S. (2000). Multiple perspectives on continuity in early learning and the transition to school. Paper presented at the European Early Childhood Research Association Conference, London.

Peters, S. (2010). Literature review: Transition from early childhood education to school. Report commissioned by the Ministry of Education. Wellington: Ministry of Education.

Petriwskyj, A., Thorpe, K. \& Tayler, C. (2005). Trends in construction of transition to school in three western regions, 1990-2004. International Journal of Early Years Education, 13(1), 55-69.

Petriwskyj, A. (2005). Transition to school: early years teachers' roles. Australian Research in Early Childhood Education, 12(2), 39-49.

Raver, C. C. (2002). Emotions matter: Making the case for the role of young children's emotional development for early school readiness. Social Policy Report, 16(3), 1-18.

Richie, J. \& Spencer, L. (1994). 'Qualitative data analysis for applied policy research', in Bryman and Burgess, eds. Analysing Qualitative Data, London: Routledge, 173-194.

Rosier, K. \& McDonald, M. (2011). Promoting positive education and care transitions for children. The Australian Institute of Family Studies, (13).

Sardjunani, N. \& Suryadi, A. (2005). Public private financing schemes for early childhood education services : Lessons learnt form Indonesia. Paper presented at symposium on Early 
Childhood Development: A priority for sustained economic growth and equity, Washington DC, September 28.

Silverman, D. (2010). Doing Qualitative Research (3rd edition). London: Sage.

Sayers, M., Moore, T., Brinkman, S. \& Goldfeld, S. (2012). The impact of preschool on children's developmental outcomes and transition to school in Australia. Manuscript submitted for publication.

Vogler, P. \& Crivello, G. (2008). Early childhood transitions research: a review of concepts, theory, and practice. The Hague: Bernard van Leer Foundation.

Whitebread, D. \& Bingham, S. (2012) School Readiness TACTYC occasional paper . available on line at http://www.tactyc.org.uk/occasional-papers/occasional-paper2.pdf

Wisker, G. (2008). The Postgraduate Research Handbook. London: Palgrave. 